\title{
Calcium and Phosphorus Requirements of Native Chicken, Hinai-jidori (Rhode Island Red X Hinai-dori)
}

\author{
Takayuki MURAMOTO*, Shinobu FUJIMURA, \\ Motoni KADOWAKI and Teru ISHIBASHI** \\ Graduate School of Science and Technology, Niigata University, \\ Niigata-shi 950-2102 \\ * Present address : Chugoku National Agricultural Experiment Station, \\ Oda-shi $694-0013$ \\ ** Present address : Faculty of Veterinary and Animal Science, Nippon Veterinary \\ and Animal Sicence University, Musashino-shi $180-8602$
}

(Received January 5, 1998)

\begin{abstract}
In order to determine the calcium (Ca) and phosphorus (P) requirements of Hinaijidori aged 42 to 56 days and of both sexes, two experiments were conducted using three parameters, i.e., body weight gain, feed efficiency and ash content of tibia of males and females. The experimental diets contained $0.52 \% \mathrm{P}$ and five graded levels of $\mathrm{Ca}$ from 0.37 to $2.48 \%$ in experiment 1 , and $0.89 \% \mathrm{Ca}$ and five graded levels of $\mathrm{P}$ from 0.39 to $0.89 \%$ in experiment 2 . The requirements of $\mathrm{Ca}$ and $\mathrm{P}$ for the maximum performance of male and female Hinai-jidori were estimated to be less than 0.90 and $0.52 \%$, respectively. However, the dietary $P$ level of males for the maximum development of bone was higher than that for the maximum performance.
\end{abstract}

Anim. Sci. Technol. (Jpn.) 69 (9): $861-864,1998$

Key words : Calcium requirement, Hinai-jidori, Performance, Phosphorus requirement, Tibia ash

The favorable taste of the native chicken meat is recognized in the world. Hinai-jidori is one of the native chickens in Japan. The feeding management of Hinai-jidori is traditional and experience-based, therefore, there are no available feeding standards for the native chickens. To estimate the nutrient requirements of Hinai-jidori, the requirements of metabolizable energy (ME), crude protein (CP), total sulfur amino acid (TSAA) and lysine of
Hinai-jidori were determined ${ }^{3-6)}$. The nutrient requirements were found to be different from those of layer pullets and broilers. However, the essential mineral requirements of Hinaijidori have not yet been determined. Growing chickens need more calcium (Ca) and phosphorus $(\mathrm{P})$ than other minerals, and many disorders caused by their deficiency were reported. There is a significant relationship between dietary levels of $\mathrm{Ca}$ and $\mathrm{P}$ and ash content of tibia

\footnotetext{
比内地鶏（ロードアイランドレッドメ比内䳕）のカルシウムおよびリン要求量：村元隆行*・藤村 忍・門脇基 二・石橋 晃 ${ }^{* *}$ (新潟大学大学院自然科学研究科, 新潟市 950-2102)

"現所属：農林水産省中国農業試験場，大田市 694-0013

**現所属：日本兴医畜産大学獣医畜産学部, 武蔵野市 180-8602
} 


\section{MURAMOTO, FUJIMURA, KADOWAKI and ISHIBASHI}

$(\mathrm{ACT})^{11)}$. The maximum growth rate of Hinaijidori is observed at the period from 42 to 56 days of age ${ }^{3-5)}$, although the growth rate of males is faster than that of females. Therefore, the present study was conducted to estimate the $\mathrm{Ca}$ and $\mathrm{P}$ requirements of Hinai-jidori of both sexes at the maximum growing phase from 42 to 56 days of age by using three parameters, i.e., body weight gain, feed efficiency and ACT.

\section{Materials and Methods}

\section{Animals}

Seventy Hinai-jidori hatched in our laboratory were sorted according to sex, and groupfed a stock diet containing $20 \% \mathrm{CP}$ and 2.90 $\mathrm{kcal} / \mathrm{g}$ of the ME diet both in experiments 1 and 2. At 42 days of age, 40 chickens were chosen, and divided into five experimental groups of four chickens of each sex with the same average body weight of $628.2 \mathrm{~g}$ for male and $561.5 \mathrm{~g}$ for female in experiment 1 , and 634.4 $\mathrm{g}$ for male and $566.2 \mathrm{~g}$ for female in experiment 2. During the experimental period, the chickens were housed individually in wire cages in an environmentally controlled room $\left(22 \pm 2^{\circ} \mathrm{C}\right.$, lights on $5: 00$ to $19: 00$ ), and given free access to the experimental diets and water for 14 days. At the end of the experiments, body weight gain and feed efficiency were determined. In experiment 2, all chickens were killed after feeding and their right tibias (Os tibiotarsi) were collected. After the tibias were defatted and dried, dry weight were measured. The ACT was determined by the procedure of A.O.A.C. ${ }^{2}$.

\section{Diets}

The composition of experimental diets is shown in Table 1. They consisted mainly of corn and soybean meal to contain all nutrients, except $\mathrm{Ca}$ and $\mathrm{P}$, not less than those for the optimum levels estimated by Muramoto et $a l^{3-5)}$. The experimental diets contained $0.52 \% \mathrm{P}$ and five graded levels of Ca from 0.37

Table 1. Composition of experimental diets

\begin{tabular}{lcc}
\hline \hline Ingredients and analysis & Experiment 1 & Experiment 2 \\
\hline Constant ingredients & 90.81 & 90.81 \\
Calcium carbonate $(40.0 \% \mathrm{Ca})$ & $0.80-6.06$ & 2.10 \\
Potassium dihydrogenphosphate $(22.8 \% \mathrm{P})$ & 1.10 & $0.52-2.73$ \\
Agar & $7.29-2.03$ & $6.57-4.36$ \\
Chemical analysis & & \\
Constant ingredients & & \\
$\quad$ Calcium $(\%)$ & 0.06 & 0.06 \\
$\quad$ Phosphorus $(\%)$ & 0.30 & 0.30 \\
Calculated analysis & & \\
Crude protein $(\%)$ & 13.15 & 13.15 \\
Metabolizable energy (kcal/g) & 2.90 & 2.90 \\
Calcium $(\%)$ & $0.37-2.48$ & 0.89 \\
Phosphorus $(\%)$ & 0.52 & $0.39-0.89$ \\
\hline
\end{tabular}

'Supplies percentage of diet: corn, 74.5 ; soybean meal, $14.2 ;$ soybean oil, $0.8 ; \mathrm{NaCl}, 0.35$; Vitamin-mineral mixture ${ }^{2}, 0.35$; Choline chloride, $0.1 ; \mathrm{L}$-arginine, $0.200 ; \mathrm{L}$-isoleucine, 0.066 ; L-1ysine, $0.054 ; \mathrm{L}$-threonine, 0.180 and $\mathrm{L}$-tryptophan, 0.010 .

${ }^{2}$ Provides per kilogram of diet:(IU) vitamin $A, 1,500 ;(\mathrm{ICU})$ vitamin $\mathrm{D}_{3}, 200$; (mg) DL- $\alpha-$ tocopherol acetate, 10 ; menadion sodium bisulfite, 0.959 ; thiamine nitrate, 1.8 ; pyridoxine hydrogen chloride, 3 ; rivoflavin, 3.6 ; vitamin $\mathrm{B}_{12}, 0.009$; biotin, 0.15 ; calcium pantothenate. 10.87 ; nicotinic acid, 26.78 ; folic acid, $0.55 ; \mathrm{MnSO}_{4}, 165 ; \mathrm{ZnCO}_{3}, 40 ; \mathrm{FeSO}_{4}, 218 ; \mathrm{CuSO}_{4}, 20 ; \mathrm{Ca}$ $\left(\mathrm{IO}_{3}\right)_{2}, 0.5$ and $\mathrm{MgCO}_{3}, 600$. 
to $2.48 \%$ in experiment 1 , and $0.89 \% \mathrm{Ca}$ and five graded levels of $\mathrm{P}$ from 0.39 to $0.89 \%$ in experiment 2. In both experiments, $\mathrm{Ca}$ or $\mathrm{P}$ was replaced by balancing with the same amounts of agar. The $\mathrm{Ca}$ and $\mathrm{P}$ contents of constant ingredients, calcium carbonate and potassium dihydrogenphosphate were analyzed by the method described in A.O.A.C. ${ }^{2)}$.

\section{Statistical analysis}

For statistical analysis, one-way analysis of variance was employed using the General Linear Model procedure of $\mathrm{SAS}^{\circledR 8)}$. Significant difference between means was determined with the least significant difference test ${ }^{10}$.

\section{Results and Discussion}

In the previous reports, to determine the requirements of ME, CP, TSAA and lysine, the dietary $P$ was set at $0.55 \%$, and the maximum performance was achieved. Therefore, in experiment 1 , the dietary $\mathrm{P}$ was set at $0.55 \%$. The dietary $\mathrm{P}$ was calculated to be $0.52 \%$.
The data obtained in experiment 1 are summarized in Table 2. With increasing dietary $\mathrm{Ca}$ levels, the body weight gain and feed efficiency in both sexes increased, and then decreased. In both sexes, the maximum performance was achieved at $0.90 \% \mathrm{Ca}$. The Ca requirement of Hinai-jidori was estimated to be less than $0.90 \%$. Therefore, the dietary $\mathrm{Ca}$ was set at $0.90 \%$ in experiment 2 . The dietary Ca was calculated to be $0.89 \%$.

The data obtained at experiment 2 are summarized in Table 2. The body weight gain and feed efficiency in both sexes increased, and then decreased with increasing dietary $\mathrm{P}$ levels. In both sexes, the maximum performance was achieved at $0.52 \% \mathrm{P}$. The $\mathrm{P}$ requirement of Hinai-jidori was estimated to be less than $0.52 \%$.

With increasing dietary $P$ levels, the ACT increased, and then decreased in males, but increased, and then remained at high levels in females. In females, the ACT achieved at

Table 2. Performance of male and female Hinai-jidori fed diets with $0.52 \%$ phosphorus $(\mathrm{P})$ and five graded calcium (Ca) levels (experiment 1), and performance and ash content of tibia (Os tibiotarsi) of male and female Hinai-jidori fed diets with $0.89 \% \mathrm{Ca}$ and five graded $\mathrm{P}$ levels (experiment 2) for 42 to 56 day of age ${ }^{1}$

\begin{tabular}{|c|c|c|c|c|c|c|c|}
\hline \multirow{2}{*}{$\mathrm{Ca}$} & \multirow{2}{*}{$P$} & \multicolumn{2}{|c|}{$\begin{array}{c}\text { Body weight } \\
\text { gain }\end{array}$} & \multicolumn{2}{|c|}{$\begin{array}{c}\text { Feed } \\
\text { efficiency }\end{array}$} & \multicolumn{2}{|c|}{$\begin{array}{c}\text { Ash } \\
\text { content }\end{array}$} \\
\hline & & Male & Female & Male & Female & Male & Female \\
\hline \multicolumn{2}{|c|}{ (\% of diet) } & \multicolumn{2}{|c|}{ (g/ 14 days) } & \multicolumn{2}{|c|}{$(g / g)$} & \multicolumn{2}{|c|}{ (\% of tibia) } \\
\hline 0.37 & 0.52 & $312.5^{b}$ & $237.3^{\mathrm{ab}}$ & $0.301^{\mathrm{ab}}$ & $0.289^{b}$ & - & - \\
\hline 0.90 & 0.52 & $369.8^{a}$ & $271.1^{\mathrm{a}}$ & $0.350^{a}$ & $0.324^{a}$ & - & - \\
\hline 1.43 & 0.52 & $319.4^{b}$ & $254.4^{a b}$ & $0.335^{\mathrm{ab}}$ & $0.299^{b}$ & - & - \\
\hline 1.95 & 0.52 & $308.8^{b}$ & $226.5^{\mathbf{b}}$ & $0.327^{\mathrm{a} s}$ & $0.277^{\mathrm{b}}$ & - & - \\
\hline 2. 48 & 0.52 & $243.5^{c}$ & $153.2^{c}$ & $0.280^{b}$ & $0.216^{c}$ & - & - \\
\hline \multicolumn{2}{|c|}{ Pooled SE } & 13.7 & 10.7 & 0.009 & 0.009 & 一 & - \\
\hline 0.89 & 0.39 & $281.1^{b}$ & 197. $9^{\mathrm{b}}$ & 0. $239^{\mathrm{b}}$ & $0.204^{\mathrm{b}}$ & $38.8^{b}$ & $37.6^{\mathrm{b}}$ \\
\hline 0.89 & 0.52 & $353.2^{a}$ & $271.6^{a}$ & $0.276^{\mathrm{a}}$ & $0.274^{\mathrm{a}}$ & $40.6^{\mathrm{ab}}$ & $40 \cdot 4^{a}$ \\
\hline 0.89 & 0.64 & 359. $2^{\mathrm{a}}$ & $271.9^{a}$ & $0.281^{\mathrm{a}}$ & $0.238^{a b}$ & $42.5^{\mathrm{a}}$ & $42.5^{a}$ \\
\hline 0.89 & 0.77 & $338.1^{a b}$ & $251.7^{\mathrm{a}}$ & $0.266^{\mathrm{ab}}$ & $0.255^{a b}$ & 41. $2^{\mathrm{ab}}$ & 41. $7^{a}$ \\
\hline 0.89 & 0.89 & $282.6^{\mathrm{b}}$ & $203.4^{\mathrm{b}}$ & $0.236^{\mathrm{b}}$ & $0.207^{\mathrm{b}}$ & $40.8^{b}$ & 41. $7^{\mathrm{a}}$ \\
\hline \multicolumn{2}{|c|}{ Pooled SE } & 11.3 & 9.0 & 0.006 & 0.009 & 0.4 & 0.5 \\
\hline
\end{tabular}

Values are means of four chickens.

${ }^{\mathrm{a}-\mathrm{r}}$ Means within each column with no common superscripts are significantly different $(\mathrm{P}<0.05)$. 


\section{MURAMOTO, FUJIMURA, KADOW AKI and ISHIBASHI}

$0.52 \% \mathrm{P}$ was higher than that achieved at $0.39 \%$ P. However, there were no differences in ACT of males between $0.39 \% \mathrm{P}$ and $0.52 \% \mathrm{P}$. Females were more sensitive to $P$ deficient diet than males. In Hinai-jidori, males were more sensitive to $P$ excess diet than females as observed in broilers ${ }^{11}$. The maximum ACT was observed at $0.64 \% \mathrm{P}$ and $0.52 \% \mathrm{P}$ in males and females, respectively. The optimum levels of $\mathrm{P}$ of males for ACT was higher than that for performance. During the growing stage, the dietary $\mathrm{P}$ levels for maximum performance of males might be insufficient to the maximum development in tibias. Therefore, the $\mathrm{P}$ requirement of male Hinai-jidori was estimated to be less than $0.64 \%$.

The $\mathrm{P}$ requirements of layer pullets and broilers are recommended to be 0.55 and $0.60 \%$, respectively, at the corresponding stage by Japanese Feeding Standard for Poultry (1992) ${ }^{1}$. The $P$ requirement of male Hinai-jidori was similar to that of layer pullets and broilers. In females, however, the $P$ requirement was lower than that of layer pullets and broilers. Because the ACT in females were not sensitive to $P$ excess diet, the optimum levels of $P$ for females might be higher than the levels estimated here. The $\mathrm{P}$ requirements for Hinaijidori in both sexes may be similar to that for layer pullets and broilers.

At the corresponding stage, the $\mathrm{Ca}$ and nonphytate phosphorus (NPP) requirements are recommended to be 0.80 and $0.35 \%$ for layer pullets and 0.80 and $0.30 \%$ for broilers by NRC $(1994)^{7)}$. The Ca: NPP ratios were calculated to be $2.3: 1$ for layer pullets and $2.7: 1$ for broilers, respectively. It is reported that the best availability of $\mathrm{Ca}$ and NPP for development of bone was achieved at $\mathrm{Ca}: \mathrm{NPP}$ ratio $2.2: 1$ in broilers ${ }^{9)}$. The Ca requirement of Hinai jidori was similar to that of layer pullets and broilers. Therefore, the Ca: NPP ratio in Hinai-jidori might be similar to that in layer pullets and broilers.

The NPP requirements for chickens are not affected by the difference in feedstuffs, however, the $P$ requirements for chickens are varied with the NPP contents in feedstuffs. Therefore, it is necessary to pay attention to the NPP contents in feedstuffs when the $P$ requirements of Hinai-jidori is referred to.

\section{References}

1) Agriculture, Forestry and Fisheries Research Council Secretariat. Japanese Feeding Standard for Poultry. Central Assoc. Livestock Ind, Tokyo. 1992.

2) Association of Official Analytical Chemists. Official Methods of Analysis. 14 th rev. ed. Assoc. Off. Anal. Chem. Washington, DC. 1980.

3) Muramoto T, Fujimura S, Ishibashi T. Effects of dietary amino acid and metabolizable energy levels on performance of native chicken, Hinai-dori. Jpn. Poult, Sci., 31 : 93-102. 1994.

4) Muramoto $T$, Fujimura $S$, Kadowaki $M$, Ishibashi $T$. Total sulfur amino acid requirements of native chicken, Hinai-jidori. Anim. Sci. Technol. (Jpn.), 67 : 764-771. 1996.

5) Muramoto $T$, Fujimura $S$, Kadowaki $M$, Ishibashi $\mathrm{T}$. Lysine requirements of native chicken, Hinai-jidori (Rhode Island Red $x$ Hinai-dori). Anim. Sci. Technol. (Jpn.), 68 : 459465. 1997.

6) Muramoto $T$, Fujimura $S$, Kadowaki $M$, Ishibashi T. Effects of excess dietary lysine and total sulfur amino acid on carcass yield of native chicken, Hinai-jidori (Rhode Island Red $\times$ Hinai-dori). Anim. Sci. Technol. (Jpn.), 68: 952-955. 1997.

7) National Research Council. Nutrient Requirements of Poultry. 9 th rev. ed. National Academy Press. Washington, DC. 1994.

8) SAS Institute Inc., SAS User's Guide. Version 5 ed., Cary, NC. 1985.

9) Sekine $T$, Watanabe $E$, Ishibashi $T$. Influence of dietary amino acids and calcium-available phosphorus on bone development of female broiler chicks. Anim. Sci. Technol. (Jpn.), 65 : 999-1007. 1994.

10) Snedecar GW, Cochran WG. Statistical Methods, 7 th ed. Iowa University Press. Ames, IA. 1980.

11) Yoshida $M$, Shoya $S$, Sueyoshi M, Mizuno $T$. Effect of dietary levels of calcium and phosphorus on growth and bone formation of female broiler chicks. Jpn. Poult. Sci., 25 : 305311. 1988. 